\title{
Endurance, identity, and temporality: the ethnic labor market and labor process of Chinese migrant workers in France
}

Juan Du

\author{
Correspondence: azalee73@gmail. \\ com \\ CERI (Center for International \\ Studies), Sciences Po, Paris, France
}

\begin{abstract}
Workers in France enjoy strong legal protections of their rights, and they have developed organizational support through unions. However, Chinese immigrant workers suffer from adverse working conditions and extreme labor precariousness. Paradoxically, they rarely turn to legal institutions for help. Nor do they organize themselves in unions. Instead, they choose to endure their exploitation. Based on an ethnographic study of Chinese immigrant workers in a Paris suburb, this paper investigates different factors that may influence their preference for resistance strategies. This paper begins with an analysis of the typology of exploitation and later proposes two possible explanations for Chinese immigrant workers' preferences. Finally, it explores the formation of migrant worker subjectivity.
\end{abstract}

Keywords: Chinese migrant workers, Exploitation typology, Labor process, Temporality, Subjectivity

\section{Introduction}

After the Second World War, along with large-scale municipal reconstruction in various states, European countries ushered in a period of rapid postwar economic development. In France, the period from 1945 to 1973 was called "The Glorious Thirty (Les trente glorieuses)." Urgent demand for labor and the lack of a French local labor population due to postwar reconstruction and economic development produced an intense contradiction; since the 1960s, France began to import large quantities of foreign labor from its former colonies, particularly from the Maghreb region of North Africa (in particular Algeria, Morocco, and Tunisia). This group of laborers was later called by migration researchers "birds of passage" (Piore 1979), "guest workers" (Castles 2006), or immigrant workers (Castles and Kosack 1973; Granotier 1970).

As the immigration of these foreign workers was supposed to be temporary, the French government originally envisaged that when these individuals were no longer needed, the country could cancel their employment contracts and repatriate them back to their countries of origin at any time. However, to the surprise of the French government, many migrant

(c) The Author(s). 2020 Open Access This article is licensed under a Creative Commons Attribution 4.0 International License, which permits use, sharing, adaptation, distribution and reproduction in any medium or format, as long as you give appropriate credit to the original author(s) and the source, provide a link to the Creative Commons licence, and indicate if changes were made. The images or other third party material in this article are included in the article's Creative Commons licence, unless indicated otherwise in a credit line to the material. If material is not included in the article's Creative Commons licence and your intended use is not permitted by statutory regulation or exceeds the permitted use, you will need to obtain permission directly from the copyright holder. To view a copy of this licence, visit http://creativecommons.org/licenses/by/4.0/. 
laborers did not return to their countries of origin after work but instead settled in France. In the 1970s, the French government began to close the border and firmly restrict the entry of immigrants. At the same time, for humanitarian considerations, the French government introduced a family reunion (regroupement familial) policy in 1976 that provided policy support for migrant workers living alone to reunite with their spouses and children in France. ${ }^{1}$ This "root-taking" made the stay of these foreign laborers no longer a temporary condition; in this sense, they became de facto permanent migrants. In their daily interactions with French society, due to differences in culture, religion, lifestyle, and socioeconomic conditions, various problems occurred in their process of integrating into French society, such as encountering racial inequality, social segregation, and racist discrimination. ${ }^{2}$ This also constituted the core issue of the sociology of immigration in France that began in the 1970s.

\section{Research questions raised}

When entering France, migrant laborers initially worked side by side with local workers in Fordistic large factories (Granotier 1970; Castles and Kosack 1973). With the advent of the postindustrial era, an increasing number of migrant workers have gradually dispersed from the assembly lines of large factories to various economic fields and have replaced local workers in certain fields. There are two points to note. First, most of their employment is concentrated in fields that require the bottom-level labor that locals are unwilling to engage in, which is what we often call 3D work (Dirty, Difficult, Dangerous). Second, as industrial workers are dispersed among small and medium-sized enterprises, the mobilization model has shifted from the originally large-scale industrial enterprise-based mobilization to sector-based mobilization (Milkman 2006). However, the status of migrant workers has forced such mobilizations to cope with the challenge of "fragmentation of identity." At the same time, with the improvement of working-class welfare and the institutionalization and regularization of various social movements, including labor movements, the French labor movement is facing a difficult situation.

Therefore, with the gradual decline in the former French working class and the growth of foreign workers in the labor market, French social science researchers have turned their attention to these emerging groups of migrant workers. Since the 1970s, they have been asking, "Can migrant workers who have both the identity of immigrants and workers constitute a new working class? Under what circumstances can they take collective action to form a new social class?" (Tripier 1990). The increasing number of Chinese migrants arriving in France has gradually formed a very important part of the French immigration wave and has increasingly interacted with French society. In this case, the same questions were naturally raised concerning the Chinese migrant labor group.

The composition of Chinese immigrants in France ${ }^{3}$ can be divided into three parts: Chinese immigrants from Southeast Asia, from Wenzhou, and from other parts of mainland China

\footnotetext{
${ }^{1}$ France's various policies on immigration are not consistent but instead are full of contradictions. There are often differences between policies due to different ideas, logic and values. Among them, the biggest differences are the immigration policy and the social security policy. The former considers the economy and emphasizes the sovereignty of the country at the political level and the latter emphasizes universal human rights.

${ }^{2}$ The research and discussion of these aspects are numerous and will not be repeated here.

${ }^{3}$ French academics customarily refer to all people who have migrated from countries or regions outside their home country as immigrants; therefore, Chinese students or dispatchers are considered to be part of the Chinese immigrant population. The term "Chinese immigrants" in this article takes a narrower meaning, that is, a group of Chinese immigrants who have migrated to France for political or economic purposes, mainly as labor.
} 
(mainly from Fujian, the three northeastern provinces, and several northern provinces). ${ }^{4} \mathrm{Al}$ though this classification is slightly too generalized, it offers expedience. It combines in one grouping the time of immigration, the geographical origin of immigrants, and the type of immigrants. The earliest immigrants were Chinese and their descendants were of Southeast Asian origin. Most of them fled to France as political refugees during the anti-Chinese riots in Southeast Asian countries in the mid to late 1970s. The large-scale immigration wave from Wenzhou started in the period of China's reform and opening-up in the 1980s and has continued to the present day, but the trend has slowed significantly in the past decade. Wenzhou immigrants are family who immigrate for economic reasons. Their characteristic traits are their family, work, and life are mainly carried out in France rather than in China. A large portion of the immigrants who arrived in France after 2000 came from Northeastern China. Many of them were laid-off workers in the state-owned enterprise, which began a privatization reform campaign in the 1990s. In the market-oriented reform of the state-owned economy, in just a few years, these individuals and their families experienced a sharp decline in their social class. They hoped that through international migration, they would make improvements in their life that could not be achieved in their home country. In the past two or three decades, although Chinese people have continuously joined the tide of labor immigration, in studies on the political participation of immigrants (including undocumented immigrants) in receiving countries, such as participating in labor unions and strike movements (Barron et al. 2011, 2014; Kahmann 2015; Tapia and Turner 2013), few Chinese immigrant workers were observed. Even if they participated in a strike, their strike pattern was "inconsistent with what French CGT trade unionists were expecting (peu conforme à ce que des syndicalistes CGT français entendaient)" (Jounin 2014: 145). The "absence" or "inconsistency" of this group makes the following paradox even more confusing: On the one hand, compared with local workers, the working conditions and wages of Chinese immigrant workers are so poor that in France, some scholars even call it "extreme exploitation (l'exploitation extrême)" or "new forms of slavery" (Gao and Poisson 2005a, 2005b). However, in France, migrant workers have the same rights as local national workers, their rights are protected by labor laws, and they enjoy corresponding political rights such as the freedom of association and the freedom to strike. In addition, French labor unions have developed very maturely, forming a political force sufficient to bargain with state power and employers. Therefore, labor groups, including undocumented immigrant workers ${ }^{5}$ who have not obtained work permits, can fully protect their rights and interests through the help of labor unions and through legal means when their interests are violated.

If one says that domestic migrant workers are weak because of the limitation of their "associating power" and "structuring power," which affects their degree of organization (Liu 2011), then one should acknowledge that Chinese immigrant workers in France,

\footnotetext{
${ }^{4}$ In this classification system, the situation of large-scale Fujian immigrants in France after 2000 is more complex and difficult to generalize. From a time perspective, Fujian immigrants are among the newly emerging immigrants. However, from the perspective of the migration model, Fujian immigrants can be divided into two categories: some Fujian immigrants consider France as a "transit country," as the final destination of their migration is the United Kingdom on the other side of the English Channel, but this phenomenon is invisible among other Chinese immigrants. Another portion of Fujian immigrants has settled in the "transit country" and set up a business in France or received their wives and children in France through "family reunion" and became an "immigrant family" similar to Wenzhou immigrants.

${ }^{5}$ Regarding the rights of undocumented immigrants as workers, some labor unions have explained and publicized these clearly (Some promotional materials can be found at http://www.cnt-f.org/sam/IMG/pdf/4 pages_sams-Paierscourt. Pdf), but there are still many undocumented immigrants who have no knowledge of their legal rights.
} 
who are no longer affected by these restrictions, are living in a situation where both "associating power" and "structuring power" are significantly socially influential. However, the reality is that when their legal rights are violated, Chinese immigrant workers still rarely join labor unions or participate in collective public resistance. They are more inclined to adopt individual level, hidden, "weapons of the weak" (Guo 2002; Scott 1985) types of struggles than engage in collective level, open, confrontational conflicts. How can we understand this preference for action?

This study uses Chinese labor in Paris and its surrounding suburbs as an example to explore the multiple factors that affect their choice of resistance strategies to discuss labor process issues in the context of international immigration. Based on this, the issue of the subjectivity of Chinese immigrant workers in the context of globalization is explored.

\section{Methodology: fieldwork entry and methods}

I conducted research in an immigrant neighborhood (hereinafter referred to as Community G) located in the eastern suburbs of Paris (hereinafter referred to as City B). At the beginning, my entry into the field was not very smooth. First, although there are many Chinese immigrants in Community G, there is no one who plays the role of "gatekeeper" (Whyte 1956). In addition, although we are all Chinese, I, because of differences in dialect, region, culture, and life experience, was still considered an outsider, the "other," and was not trusted.

To establish a trustful relationship, before the formal interviews began, I regularly appeared in Community $\mathrm{G}$ for a long time and provided free translation services to let local residents get used to my presence while at the same time conducting participant observation. After more than 6 months of "presence," I finally found my "position" in Community G (Beaud and Weber 2010). ${ }^{6}$ Therefore, the survey I conducted combined research methods such as participant observation, informal chats, and in-depth interviews to collect data. The empirical materials and data on which the analysis in this article is based are mainly from my field survey of Community G from 2013 to 2017.

City B is located close to eastern Paris and is a convenient area for immigrants. Community $\mathrm{G}$ is the smallest of seven blocks. Immigrants living in this neighborhood account for $54 \%$ of all residents, far exceeding the average level of the province of SeineSaint-Denis (26\%); ${ }^{7}$ among them, Asian immigrants account for nearly half, or $25 \%$ of all residents in Community G, among which immigrants from mainland China account for a large proportion. ${ }^{8}$ My research mainly focuses on new immigrants, that is,

\footnotetext{
${ }^{6}$ The term "position" has its methodological significance, emphasizing the relevance of the position of the researcher in the field survey: this "position" is not given by the researcher to himself or herself, nor is it entirely given by the interviewees. This is a social role for an outsider, which is a result of a "negotiation" between the two sides in a particular social situation.

${ }^{7}$ Statistics are from National Institute of Statistics and Economic Studies (INSEE). The national census is the responsibility of this official institute.

${ }^{8}$ According to the internal data of the "Social Diagnostic Report," "the vast majority of Chinese immigrants come from the coastal city of Wenzhou in Zhejiang Province." This report is a social diagnosis submitted in 2008 for urban renewal of the neighborhood. The report uses social survey methods and employs Chinese translators to facilitate communication with Asian families, so the data is relatively credible. However, considering the fact that this survey was done more than 10 years ago, coupled with the phenomenon of "dapu" that is common in Chinese housing (a subletting type of living, see Du, 2014 for details), the proportion of Chinese residents actually living in Community G should be higher. According to the number of names on the mailboxes, my rough estimation of the proportion from that report is $1 / 3$ to $1 / 2$ of the actual current number.
} 
immigrants who came to France after 2000. Some of them still have no legal residence permits and are therefore in a state of illegal immigration; others have regularized their situation and obtained their legal residence permits.

Of these new immigrants, the most came from Wenzhou of Zhejiang Province, followed by Fuqing of Fujian Province, and many from Tianjin, Hebei, Henan, and Shandong. The new immigrants are also different in age distribution and gender ratio. Generally, the new immigrants from Wenzhou are mainly young adults; most of them are 30-40 years old, and most of them live in France as a family, so the gender ratio is more balanced. The ages of immigrants from the northern provinces of China are relatively older, mainly between 40 and 60 years old. Most of them live alone, while their spouses and children stay in China, and only occasionally are both spouses in France. The situation of immigrants from Fujian is more complicated. Some middle-aged men are alone, working in France, aged between 40 and 60. Some are young people who work and live in France as a family. Most of them are aged between 20 and 35.

From the perspective of education level, most new immigrants have only received primary or secondary education; Chinese labor immigrants with higher education are relatively rare. Very few people are fluent in French, and language has become an insurmountable obstacle for most Chinese labor immigrants. This is also a restrictive factor that causes many Chinese workers to tend to find jobs in the internal labor market of their own ethnic group.

From the perspective of residents' income level and occupation category, most residents in Community G belong to the low-income social class. Chinese residents are no exception. Except for a very few people who have already set up their own companies and become bosses, most Chinese residents are still "working for others," with employment concentrated in the clothing, renovation, and catering industries. The wage level is generally the legal minimum wage ${ }^{9}$ or slightly higher.

In terms of research methods, in addition to the combination of the various methods mentioned above, I also collected a large number of Chinese immigrant netizens' opinions and disputes on work and exploitation from France's largest Chinese forum "Huarenjie (Chinese Street)." ${ }^{10}$ Discourse analysis of the data is used as supplementary material for this article. I referred to information from multiple channels, ruling out the possibility of paid cyber posters. The analysis of online discourse has specific methodological significance for this research. On the one hand, due to various complex and restrictive factors in real life, the interviewees usually do not discuss the topic of work in depth. Even if the interviewer deliberately guides and asks, they often do not feel that they have the need to speak publicly. However, in an anonymous environment of equality created by the Internet, once controversial topics emerge, their enthusiasm for participating in discussions and speaking is greatly mobilized, and a form of "collective discussion" that relies on Internet anonymity appears. This is helpful for researchers not only to analyze the justification of Chinese immigrants and the logical relationships

\footnotetext{
${ }^{9}$ France implements the minimum wage system, or SMIC for abbreviation, and readjusts on January 1, of each year according to the purchasing power and wage level of the previous year. The minimum wage (gross) in 2017 is 9.76 euros per hour. Based on the legal working hours of $35 \mathrm{~h}$ per week, the gross salary is 1480 euros per month and the net wage is 1153 euros. The monthly wages of the Chinese immigrants I interviewed mostly range from 1,100 to 1,200 euros.

${ }^{10}$ The main users in the forum are Chinese immigrants in Europe, of which the Chinese groups in France, Italy and Spain are the most active ones (http://faguo.huarenjie.com/).
} 
behind it (Boltanski and Thévenot 1991) but also to adjust and modify the direction of interviews and investigations. On the other hand, according to the view of symbolic interactionism, comprehensive social science research cannot be limited to only one end of a certain type of relationship; rather, the two parties to this relationship, or even the three parties, and their relationship as a whole should be studied. If I want to study exploitation and resistance, I cannot just be satisfied with the investigation and study of the working class. However, the actual situation is that in the community surveyed in this research, I usually have more contacts with the labor class, and only a few interviewees belong to the employer class; however, many "bosses" often participate in discussions in online forums ${ }^{11}$. Their participation makes the argument richer and more diverse.

\section{Chinese ethnic labor market and its characteristics}

\section{Ethnic labor market}

Traditionally, Chinese immigrant laborers are generally concentrated in three major economic sectors, commonly known as the "three kinds of knives," namely, kitchen knives, scissors (in Chinese, literally "shearing knives") and leather knives, corresponding to the catering industry, clothing industry, and leather goods industry, respectively. However, in the past 10 years, these traditional ethnic economic fields have all experienced some changes. On the one hand, the catering industry, under a diversification process, is still one of the most important ethnic economies and continues to receive, absorb, and employ a large number of Chinese immigrants, while the clothing industry is affected by the French economic crisis and the rapid development of the Chinese import and export trade; therefore, it can provide a diminishing number of employment opportunities for Chinese immigrants. Meanwhile, the leather goods industry has almost disappeared. New economic fields have also gradually formed, and the renovation industry has now become an important market for absorbing Chinese labor. ${ }^{12}$ In addition, the economic activities of Chinese immigrants have also undergone a huge change: if most of the late-twentieth-century immigrants were concentrated in the manual labor industries that did not require high education and professional skills, then after 2000, the economic activities of Chinese immigrants show a trend of

\footnotetext{
${ }^{11}$ Of course, there are methodological risks in researching disputes on the Internet. For example, how to prove that a netizen speaking from the boss's standpoint is truly a boss in real life, that is, how can one's social identity be verified? Reasons for the exclusion of cyber astroturfers are as follows: (1) The size and economic strength of the French Chinese cannot support a specialized paid cyber poster market; therefore, this demand cannot be marketized. (2) I also referred to information from multiple channels when conducting online collections of forum data. For example, there is a personal webpage behind each user ID of the forum. Click on the post and one can see activities, public diaries, and photos. Those users were not registered at the time when they posted or participated in the discussion, and many users still have traces of activities, such as other posting records, as well as diaries, photos, etc. In addition, the content of those users' responses is very rarely repetitive but targeted in response to the main post or certain reply post, expressing their own opinions and ideas, so I can also rule out the possibility of a paid poster in terms of content. (3) After reading all the replies, I summarized several discussion directions. Here, I do not intend to discuss which opinions were dominant, but instead I will pay attention to the different value logic behind these opinions, that is, how those netizens justify their opinions.

${ }^{12}$ The renovation industry is mainly composed of two major economic activities: one is interior renovation, which includes the internal renovation of shops, as well as the maintenance and renovation of living spaces; and the other is the provision of materials for interior renovation. Due to the large number of Chinese running businesses in the building material sector, in 2010, they established an association in the number 93 province near Paris (that is, the Province of Seine-Saint-Denis), named the "French-Chinese Construction Industry Federation (Association A.S.F.C.T)."
} 
diversification. The scope of their employment has gradually expanded to various fields, covering occupations with high professional skills (such as lawyers and accountants) to occupations with very low or no professional skills (such as live-in nanny and restaurant dishwasher). Among these diverse immigrant groups, I am most concerned with immigrant labor groups at the bottom of society, regardless of whether they have legal status.

Working for bosses of the same ethnic group is very common among Chinese laborers, and it even forms a self-contained "intragroup labor market" (Wang 2000; Zhou 2010) or "ethnic labor market" (Ma Mung 2005): Chinese workers, Chinese employers, plus a set of established orders that differs from the formal labor market. Not every immigrant group has formed an ethnic labor market. The reason why the Chinese ethnic market can be formed is mainly affected by two aspects, according to my personal understanding.

First, compared with immigrants from other ethnic groups, the proportion of "handicraftsmen, businessmen and bosses" among Chinese immigrants is very high (13\%), ${ }^{13}$ much higher than other immigrant groups (this occupational category comprises $5 \%$ of Senegalese immigrants, 3\% of Mali immigrants, and even for Algerians only 8\%). This means that they can provide more job opportunities, facilitating the most fundamental market conditions for the formation of the intragroup labor market.

Second, it is difficult for Chinese laborers to adapt to the social, political, and economic institutional arrangements in which they live. France has a set of immigration laws to manage and regulate foreign immigrants and crack down on companies that hire undocumented immigrants. ${ }^{14}$ In addition, the French formal labor market also excludes immigrant workers by requiring a minimum education level, language skills, and certified professional skills. Most immigrant workers are not well educated and lack professional training. They also face language barriers and status issues (i.e., whether they are legal immigrants). Because of their limited resources, they have few opportunities to find jobs in the mainstream market and can only turn to ethnic networks to seek information and job opportunities.

\section{Job hunting and approach preferences}

There are generally two ways for Chinese immigrants in France to find a job: one is through relationships, that is, the social networks of individuals; the other is to obtain the required information through Internet information platforms. Rather than use the Internet, Chinese immigrants are more inclined to use personal networks to find jobs; this applies equally to both bosses and workers. If a suitable job or worker cannot be found through their own networks, Chinese immigrants will turn to the information platform on the Internet. Many of the people interviewed for this article found jobs or workers through personal networks.

Mr. Li ran a shop and needed workers. It happened that his neighbor, Ms. Chen, had recently resigned, and Mr. Li asked if she wanted to work in his shop.

\footnotetext{
${ }^{13}$ See statistics from National Institute of Statistics and Economic Studies (INSEE) in 2006. The percentage of Chinese engaged in handicrafts or as businessmen and bosses in France is second only to Brazilians (17\%) and Turks (15\%), and it is also higher than the average immigrant groups (10\%).

${ }^{14}$ According to French law, entrepreneurs who hire undocumented immigrant workers face a 5 -year prison sentence and a fine of 1500 euros for each undocumented worker employed (Article 8256 (2) of the Labor Law).
} 
Xiaochuan used to work for a Chinese renovation company in Community G. Earlier, she met with her boss at the community center. Later, when the company needed a secretary, the boss contacted her directly. The workers in this renovation company are almost all Fujian fellow natives.

A resident of Community G started his own restaurant. The chef of the restaurant was the younger brother of a neighbor.

Ms. Ye's husband opened a self-service restaurant in a French province, and the waiter was Ms. Ye's nephew.

From the above examples, we can clearly see that this so-called relationship network is woven strongly or weakly by blood (such as Ms. Ye's nephew), geography (the fellows from a hometown or a neighbor in the current place of residence), and profession (former colleagues). In his study on how one gets a job, Granovetter focused on whether strong or weak ties can more effectively provide individuals with job opportunities, in other words, what possibilities a particular structure can provide to individuals (Granovetter 2007/1985). Here, we deal with this issue from the opposite angle, that is, from the perspective of the subjective initiative of immigrants, as the starting point of analysis, to explore whether they prefer to find jobs through strong or weak ties.

Based on interviews with residents of Community G, Chinese immigrants try to avoid jobs found through strong ties. Friends can help each other, but this close relationship does not apply to the workplace. "If you want to come to my shop for learning skills, that is ok. But we need to say it well in advance that after you finish your skill learning, you should use it elsewhere... If you are the boss and you see a friend standing there idling, you are embarrassed to point it out to him; if you are the worker, what you think is that the boss only sees when we are not busy, but we are too tired to die when we are busy, yet it is not easy to speak it out... in the end, even friendship will not be able to continue." (20141015, Interview with Ms. Chen).

This preference in turn reveals the possibility of conflict in industrial relations and power relationships in the workplace. Once the two parties enter the workplace, there will be many problems surrounding the identity of the boss versus worker, and the emotional connection from the acquired strong ties makes it difficult for both parties to further follow the original "hidden transcripts" to deal with industrial relations and relationships of domination in the workplace (Scott 1990). Because of individuals' sensibilities, the dissatisfaction of both sides cannot be expressed and communicated in time; rather, the misunderstandings and contradictions deepen, which eventually will lead to the break of the acquired strong ties.

\section{Informality and precariousness: two characteristics of the Chinese ethnic labor market}

Looking at the economic activities of Chinese immigrants, we can find that this ethnic economic field has two characteristics: informality and precariousness. Of course, these two characteristics are not unique to the Chinese labor group. The entire French labor market is trending towards informality and precariousness; it is only that these characteristics are more obvious in the ethnic market where immigrants gather, and they have even been solidified as unspoken rules in the low-skilled labor market. In the Chinese ethnic labor market, most Chinese enterprises are small and medium-sized family-run enterprises. On the one hand, employers are often involved directly in specific labor, 
and on the other hand, the number of workers is small and scattered, so the relationship between employers and workers is relatively direct, and the links between workers are quite loose. It is difficult for workers to form a common claim to their own interests, and therefore, further concerted action is even more difficult to achieve. This provides a favorable system for employers to better manage Chinese immigrant laborers.

Informality means that the economic activities undertaken by Chinese immigrants are more or less informal in nature and are not recognized by the formal economic sector of France or included in the scope of governing (such as making food at home and selling it online or vending goods on the street). Instead, the economic activities of Chinese immigrants either skirt the edge of the law or are simply illegal (such as having a job but not reporting to the relevant state department and not paying the corresponding social contribution or tax evasion). This includes both the informal part of the economic behavior of legal immigrants and the vast majority of the economic behavior of undocumented immigrants.

After a long period of "illegal stay" (Li and Zhou 2014), even if immigrant workers have their situation legalized successfully, ${ }^{15}$ it is still very difficult for them to shed this informality. Reasons for this situation are complex. In short, immigrant workers in an absolutely disadvantaged structural situation are forced to accept this imposed informality in the end. There have been many studies on the long working hours and low wages of Chinese people (Gao and Poisson 2005a, 2005b; Auguin 2010). In addition, the social rights of Chinese workers are often undermined. According to French labor law, employers must prepare a contract in compliance with the law before the workers officially take the job. The contract goes into effect after being signed by both parties and workers' rights are protected by the labor contract. However, the actual situation I investigated shows that laborers usually have no contract after working for some time. For example, Ms. Ou, a resident of Community G, just got her first residence permit in early 2014 and worked in a nearby garment factory. There were many other Chinese female workers in the same factory. She repeatedly asked her boss for a work contract, but it was delayed for various reasons by the boss. After working for more than 5 months, she never received her job contract, and her payroll was never issued on time.

Even with labor contracts, the situation is similar to this case, as is the provision of other supporting documents. For example, the French Labor Law stipulates that at the end of a contract, the employer must provide a set of certificates, which is closely related to certain social rights of workers (especially unemployment insurance benefits); however, few Chinese immigrant workers can obtain this set of documents at the end of their labor contract. On the one hand, immigrant workers do not know much about the relevant policies; on the other hand, they know that the boss will not issue them documents such as the end-of-contract certificate. Therefore, after losing their jobs, they rarely go to social security institutions such as the Employment Center (Pôle d'emploi) or Family Assistance Center (Caf) to apply for social security benefits. Instead, they choose to accept the status quo and immediately reenter the labor market.

Another characteristic is its precariousness. This means that the rights and interests of workers as subjects of economic behavior are easily affected by changes in the economic

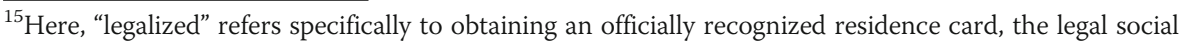
status, and a work permit.
} 
situation and employers' wishes, mainly referring to the lack of long-term protection for on-the-job status and salary, always being forced to live in a changing, fluctuating, or unpredictable situation. The precariousness of work directly affects the socioeconomic status of workers, leaving them in a fragile and vulnerable social situation in the long run. For example, Ms. Jia and her husband in Community G obtained their legal status in July 2013. One year later, she changed her job, stopping work in a garment factory and starting to work in a restaurant instead. Her husband, who did renovations, however, kept changing company every 2 or 3 months. "Working in renovation business is like this. Change to another company if there's no more work for you."

The Chinese ethnic economy, mainly based on the model of a small and mediumsized family-run business, is an economic market characterized by a high degree of flexibility for employing laborers and precariousness for laborers to be employed. Precariousness is manifested first in the high mobility of workers because bosses can fire workers at will. In the renovation industry, the employment of workers is particularly unstable, and the mobility of workers is tremendous. This is mainly due to the nature of the renovation industry, i.e., project-oriented model, which means that the bosses hire the required labor based on the availability and number of projects at hand; therefore, there is no long-term security for workers' employment and income. However, this practice is against labor laws. Employers cannot dismiss workers who have not committed major mistakes. To circumvent this law, Chinese employers usually let workers resign on their own, rather than fire them. Workers usually cooperate with the requirements of employers, thinking that they can also work "at will", to be immersed in the illusion of having strong control over their labor demand. In fact, according to the labor law, workers as employees have the right to resign, as long as the employer is notified in advance according to a prescribed time, however, the employer does not have the right to dismiss an employee at will. Therefore, the group of people who bear the cost of this highly flexible employment are disadvantaged workers.

In addition, precariousness can also be seen in the welfare and remuneration of Chinese workers. Even if a labor contract is signed, in most cases, it is just paperwork, and the specific work content and related wages and benefits must be negotiated faceto-face by the employer and the employee to reach an oral agreement. This is why immigrant workers are more inclined to find jobs through their networks. Interpersonal relationships can constitute both practical and moral constraints on the boss to reduce the possibility of violating a real contract, which is an oral agreement. In general, the causes of precariousness in the professional career of immigrant labor groups are complex, and informality is one of the most fundamental reasons. The absence of a clear contract of responsibility and the existence of verbal agreements make it impossible for workers' rights and interests to be protected, and it is impossible to effectively restrict the behavior of employers.

This is the case for workers with legal status, let alone the working situation of undocumented workers without legal status. Unstable lives and frequent unemployment are the "normality" they have to accept. They formed a group of on-call labor reserve troops. When a company is short of hands, they are always ready to fill in the gap, but when it is not, there is no job. Mr. Tu, a former resident of Community G, was plagued by unstable employment. He was engaged in renovation work and had no legal residence permit. Since April and May 2013, his employment had been intermittent. He 
complained: "I only worked four or five days this month until now (to mid-month)." Because he was particularly worried about his work, he was in a bad mood and decided to return to China in September.

Therefore, how do we understand such a paradox? On the one hand, there is a comprehensive set of labor protection laws, various institutional arrangements and a sociopolitical apparatus (Foucault 1980) for protection of the rights and interests of laborers, but on the other hand, there exists the intragroup labor market, which is characterized by informality and precariousness, and Chinese immigrant laborers who seem to "consent" (Burawoy 2008/1979) to all this. Under such a structural condition, how is the model of Chinese industrial relations possible? In the following, based on the "moral economy" theory (Scott 2001/1976) and the conceptual tools of "relationship-based hegemony (l'hégémonie fondée sur les relations)" (Shen 2008), combined with the specific context of France, I will conduct a social anthropological analysis on the subjective cognitions of Chinese migrant labor groups about "work" and "exploitation." At the same time, I want to reveal that the "temporality" dimension also plays a positive role in maintaining this labor control model.

\section{The typology of exploitation}

We have learned from the above about the working conditions of Chinese immigrant workers in France and the characteristics of the entire Chinese ethnic economy. Why do Chinese immigrant workers in such unfavorable circumstances not defend their rights and interests by joining labor unions or resorting to the law to improve their situation?

To better understand the resistance model of Chinese immigrant workers, a more detailed analysis of exploitation is needed. In fact, there is more than one form of exploitation. Based on the degree of exploitation, I divide the exploitation into two types: "chronic exploitation" and "acute exploitation." "Chronic exploitation" refers to the unspoken rules prevailing in the ethnic labor market, including long working hours, low wage income, unenforced contracts, fewer holidays, and poor working conditions. In contrast, "acute exploitation" refers to the breach of the bottom line by the employers, moving from unspoken rules into a no-rule sphere, mainly manifested as delayed wage payments (Qi 2011). Although "chronic exploitation" has continuous, long-term, and far-reaching effects on the lives and economic conditions of workers, such as normal exploitation (Scott 1985) has rarely caused open resistance by Chinese workers.

Ms. Huang's salary and subjective response are quite representative of Chinese immigrant workers. Ms. Huang received her first legal residence permit in 2012. Earlier, she did garment work at home, and she had four or five machines in a room of 20 square meters. After obtaining her residence permit, she found a formal job in a garment factory. The owner was a French-Turkish man. According to the provisions of the labor law, she signed a work contract with her boss. The contract stated that she "works 35 hours a week," for a wage of the minimum wage stipulated in the labor law. However, the actual situation was that she worked 6 days a week, $10 \mathrm{~h}$ a day, excluding 1 hour at noon for lunch; the actual work time was $9 \mathrm{~h}$ a day, and the weekly work time was $54 \mathrm{~h}$, far exceeding by more than 1.5 times the legal requirement of 35 hours per week. However, the excess time was considered "normal working time," which did not count as extra work time and provided no extra 
income. Ms. Huang commented that extra payment would only be available and calculated when the labor time would exceed the "normal labor time," when working extra "making-out" time on a Sunday. Although we have met each other many times, she rarely complained about her work. I asked a few times, but she only said, "It's all the same everywhere in the clothing industry, and it does not help to change the boss."

Obviously, Ms. Huang's salary is in sharp contrast to her attitude. How is it possible to understand this attitude of "endurance"?

The typology of exploitation helps us to better understand the mechanisms of resistance and labor control. For example, some scholars in France researched the participation of migrant workers in labor unions (Confédération générale du travail, CGT) and found not only that a high proportion of immigrants from West Africa join in labor unions but also actively participate in various movements organized by the union. A "Chinese mystery" remains that the scholar could not understand for Chinese immigrant laborers: Although many Chinese immigrants joined the union, they did not actively participate in open collective protests such as strikes or marches (Jounin 2014: 145-146). I maintain that it is precisely through the abovementioned distinction between various phenomena of exploitation that we are able to clear away the shroud around this "mystery." Only when "acute exploitation" occurs will there be open resistance. Therefore, the reason that Chinese workers join the union is mainly to facilitate the acquisition of their legal status but not to openly challenge normal "chronic exploitation."

Therefore, the resistance of Chinese immigrant workers to their bosses and "exploitation," which has attracted scholars' attention, is mostly due to protests against "acute exploitation," such as wages being in arrears. Few workers take open, collective action against daily, hidden "chronic exploitation." Even when they talk about their working conditions and remuneration, they only express their feelings in the form of "weapons of the weak," such as occasional complaints. These complaints often conclude with the same exclamation: "I am useless myself; whom should I blame for this?!" They believe that the cause of their unfavorable status quo is personal rather than social and structural. In other words, they believe that the extremely fragile and extremely precarious socioeconomic conditions accompanying them are determined by their own individual lack of abilities (education, labor skills, etc.), but not by social inequality or defects in institutional arrangements.

"Acute exploitation" and "chronic exploitation" are not completely dichotomous; one can be converted to the other. Paying wages on time constitutes a threshold for labor groups in terms of tolerating "chronic exploitation."16 Once wages are in arrears and "acute exploitation" occurs, the previously tolerated and hidden "chronic exploitation" will become prominent and enter the field of discussion. The opinion expressed by a netizen when responding to a controversial topic is exactly proof of this. "The black workers (undocumented workers) have inherently unfavorable conditions. They are originally a disadvantaged group of people and are often bullied by others very impetuously and arrogantly. You can bully as much as you can, and you can even dock wages,

${ }^{16}$ This point was mentioned in the research of Burawoy (2008/1979) and Shen Yuan (Shen 2008). Paying salaries on time is a prerequisite for the "making-out game" or "relationship-based hegemony" to proceed smoothly. 
but you cannot refuse to pay the wage, and you cannot do that just with any reason popped out from your mind." 17

Nonetheless, when labor disputes occur, Chinese immigrants still tend to resolve the conflict internally (Gao and Poisson 2005a). Sometimes disputes are resolved by both employer and employee themselves, and sometimes they need an intermediary (individual or organization) that both parties recognize. During the conflict, actors of all parties try to avoid causing the intervention and interference of a public authority, such as a labor inspector or other government department personnel. If the conflict can be resolved between employers and employees, it is considered the best result. If not, the conflict will further intensify beyond the scope of all involved parties and enter the space of public discussion (such as putting their own experiences on Internet forums), but at this stage, public discussion is still limited to the ethnic group. At that time, there are two possible directions for the conflict: either the case returns to the previous level and is resolved between the employers and employees involved, or the case might go beyond the ethnic boundary and the involved parties would actively seek the intervention of a public authority, which would mean that the conflict has reached its most intense stage. In short, when conflicts occur, immigrant workers are more inclined to resolve labor disputes with their bosses at the individual level and rarely take open collective actions. Access to the law is undoubtedly the last choice for Chinese immigrant workers.

\section{Laborer subjectivity, identity, and mechanisms of labor control}

To understand the endurance of Chinese immigrant workers in the face of exploitation, we need to consider both external restrictive factors and internal control mechanisms. External restrictive factors include the following: most Chinese workers are unaware of their rights and understand neither labor laws nor the ways and running logic of French society; moreover, they are very afraid of the intervention and interference of a public authority - the police or labor inspection authorities are often seen as administrative agencies that run counter to the interests of undocumented immigrant workers, and laborers keep away from them.

If these restrictive factors greatly limit the possibility of immigrant workers' resistance to exploitation at the practical level, it still does not explain such a situation: Even Chinese workers with legal status rarely raise objections to their working conditions and wages. To understand this silence, we need to further analyze some of the institutional arrangements that are widespread in the Chinese ethnic labor market. We took the opportunity to review a Chinese immigrant worker's complaint on an online Chinese forum and the controversy it caused to reveal these mechanisms and institutional arrangements.

\section{"I was bullied by my boss"}

A Chinese immigrant worker posted a topic on a forum on the website of Huarenjie, describing the conflict between herself and her boss (below referred to as Post 2). The

\footnotetext{
${ }^{17}$ The controversial topic is titled "Trial work, learning to work, not paying, that is, fraud, exploitation, whether or not you have legal status" (http://www.huarrenzie.com/thread-3878882-1-1.html), quoted reply was the 66th. Some of the literal format problem in this part of the quoted text are recorded according to the original.
} 
poster had truthfully told the boss that she had no residence permit and no work experience before working, and the boss agreed to let her work in the shop. After 2 or 3 days, she learned that she was unpaid. She thought that she was going to work, and naturally she had to be paid. The boss thought she was there to learn working skills, so she did not merit a salary. Therefore, the poster felt "bullied by the boss." This posted topic aroused a great number of echoes and controversy on the forum. It was posted on November 29, 2014, and the last reply was on December 2, 2014. In just 4 days, it was viewed 9796 times, and 174 replies were received. The first reply adopted the attitude of supporting the protection of workers' rights; it recommended that the worker/poster go to the boss to ask for a salary first, and both parties should resolve it privately, and if it does not work, then the poster should resort to the law to protect her rights. ${ }^{18}$ This controversial topic for the Chinese community immediately caused strong repercussions, and most of the following replies revolved around the rights and obligations of the boss and the workers and how to properly resolve the contradictions and conflicts between the two.

On December 2, another Chinese immigrant was concerned about the issue and the controversy it caused, and started a new relative post: "Trial work, learning to work, not paying, that is, fraud, exploitation, whether or not you have legal status" (Post 3). The title directly refers to "exploitation," which caused a wider and more intense debate on the above topic. This post has been viewed 5447 times and has 188 replies.

On December 8, a related new post appeared on the forum. The poster described his own experience as an example to oppose the legal solution to the contradiction: "Go and sue! Someday you will become the defendant" (Post 4). This post was viewed 1978 times, with 27 replies.

This kind of public discussion and debate is beyond our field observation when we conduct personal in-depth interviews for investigation. The following excerpts are typical of the replies.

I mean we can do these things in another way, because we are all Chinese (Post 322nd reply)

Sometimes it's not easy for everyone, all struggling for life. There is really no need to make a scenario of either the fish being dead or the net getting torn. There is humanity beyond the law. All Chinese people should support each other even more. (Post 4-6th reply)

In the face of bad bosses, for the black workers, can there only be a means of resorting to the law to defend their rights? It should be thought that other fellow Chinese, in fact, all have shared benefits, like grasshoppers tied on one rope; if the boss is sucked, how would other workers do who just get involved because of it? They will be deported, in the worst case, and in the lightest case, they have to spend money for a lawyer and lose their jobs. Think twice! (Post 4-7th reply)

\footnotetext{
${ }^{18}$ The original text of the reply, positioned $2^{\text {nd }}$ reply to the original posted topic, was: "The topic poster can inform the employer that if he truly wants to bully people like this, and the poster will then...go to the court to sue him for employing black labor and paying no wages. In this case, it is easy to sue him, and then it will make the boss pay a thousand times more".
} 
Most of us, Chinese immigrants, have come through all the way as black laborers; therefore, we should understand each other. (Post 4-26th reply)

The fisherman takes advantage from the fight between the snipe and the clam. After this season will come another, and don't burn your bridges. (Post 4-21st reply)

The fisherman is the (French) government. (Post 4-23rd reply)

\section{Literature review of labor process theory}

The study of the labor process originated with Karl Marx, who pointed out in Capital that capitalists purchase abstract labor power, which can only become actual labor when it is exerted in the labor process (Marx 1972). The pursuit of capitalist production is to maximize the surplus value, that is, to maximize the conversion of labor power sold by workers into actual labor. To this end, capitalists need to transfer the control of the labor process from workers to their own hands.

For Braverman, the basic adjustment method of capitalism is management control. Gradually, ideation activities are concentrated in the hands of a small number of managers, and workers are deskilled, thereby achieving a separation of conception from execution (Braverman 1974). This view has been widely quoted by scholars; however, at the same time, it has also been criticized. Most of the criticism has focused on the "missing subject" (O'Doherty and Willmott 2001: 457), that is, Braverman ignores the workers' subjective experiences in the workplace (Ezzy 1997: 427). As a research advancement, some scholars describe in detail the labor process and the subjectivity in the workplace (Storey 1985; Burawoy 2008/1979), in which Burawoy's research caused great repercussions: through the concept of a "making-out game," he brought workers' subjectivity of spontaneous "consent" into the study of the labor process. However, Burawoy placed too much emphasis on influencing factors in the workplace, ignoring social factors outside work, such as ethnicity, skin color, gender, and citizenship (McDowell et al. 2007). Therefore, attention to the social factors of subjectivity has become a common strategy for subsequent researchers (Shen and Wen 2014). I argue that, in these studies, the subjectivity of workers is mostly considered to be static, and it is rarely put into the dimension of temporality for a re-examination with a dynamic perspective.

With the acceleration of population movement around the world, the diversification of labor fields and labor methods, and the absorption of labor by the service industry, research on international migrant workers has also shown a diversified trend. Although the objects of research are complex and diverse, the problematiques of the research are mainly concentrated on two problem domains. First, since the 1980s and 1990s, employment has experienced flexibilization, and laborers have faced the risks of precarization. These significant social and economic phenomena specifically manifested in the informal sector, informal employment and flexible work. A large number of migrant workers are concentrated in these service-oriented industries. (McDowell et al. 2009; Milkman 2011; Anderson 2010; Alberti et al. 2013; Wilson and Ebert 2011). Among them, foreign domestic workers (Anderson 2000; Pande 2018; Paul and Neo 2018) and 
care worker groups (Maroukis 2017) have aroused the attention of academia. Because the workplace is often in a private space such as a family, multiple dimensions of gender, ethnicity, and citizenship together have an impact on this type of work. Second, attention was given to the impact of technology on laborers, working conditions, and labor relations. For example, the prosperity of the sharing economy poses a challenge to the traditional business and labor model; therefore, an increasing number of studies are trying to explore the working status and conditions of practitioners in the sharing economy (Balthasar 2017; Hall and Krueger 2018).

\section{"We are all Chinese": class identity squeezed into multiple identities}

The identity of migrant workers is complex and diverse. For Chinese immigrants, their identity is composed of multiple identities, such as ethnic identity (Chinese), regional identity, and class identity (whether they consider themselves workers).

For Chinese domestic rural migrant workers, the geographical relationship such as "fellow-townsman" affects the management and control in the labor process. Thus, for international migrants, the operating basis of this "relationship-based hegemony" (Shen 2008) is changed from "fellow-townsman" into the ethnic group. ${ }^{19}$ Among French Chinese labor groups, I observed the phenomenon that ethnic identity often overlies class identity. The abovementioned set of discourse labeled as "we are all Chinese" is often used to persuade workers to obey and to reduce conflicts and the intensity of conflicts (e.g., Post 3-22nd reply, Post 4-6th reply, and Post 4-7th reply).

As a result, industrial relations in the Chinese intragroup labor market are often obscured by an "ethnic solidarity" for working together and struggling abroad. In addition, this "ethnic solidarity" is supported by a set of discourses, such as ethnic identity, coexistence of interests ("grasshoppers tied on one rope" [Post 4-7th reply]), personal struggle under neoliberalism, and the establishment of an opposite "Other," i.e., the French government ("The fisherman takes advantage from the fight between the snipe and the clam.... The fisherman is the (French) government." [Post 4-21st and 23rd replies]). As a result, social relationships based on ethnic groups continue the labor control model of "relationship-based hegemony."

Compared with other ethnic minority groups in France, this feature is quite obvious in the Chinese ethnic group. Other immigrants, such as African immigrants, have actively participated in labor unions and strikes and marches after arriving in France. Immigrants from several West African countries (especially Malian immigrants) are more active among migrant workers. Although African immigrants also have multiple identities, such as ethnic and class identities, they do not squeeze into class identities because of ethnic identities: "They (Malian undocumented workers) may have complex loyalty relationships with their employers, but they are rarely affected by other loyalties, such as kinship, village, ethnicity, etc." (Jounin 2014: 146).

\footnotetext{
${ }^{19}$ The term "ethnic group" is used here instead of "nationality" because in the context of transnational mobility, the concept of ethnic group is more accurate than the concept of nationality, covering a broader scope than nationality and including the second generation of immigrants. It is an identity based on culture and immigration history.
} 
Through comparison, the author proposes a possible interpretive factor: the Chinese group forms an internal labor market, which can provide rich ethnic resources, especially in the field of work, and industrial relations are greatly affected by interpersonal relationships; therefore, ethnic identity is strong. In contrast, the proportion of African immigrants becoming bosses is very low, and the employment opportunities they can provide are limited. For example, Malian immigrants are mainly concentrated in the category of hired workers; $88 \%$ are employees or workers, while the average proportion of all immigrants is $65 \%$. Correspondingly, their proportion in occupational categories of craftsmen, businessmen and bosses is particularly low at only 3\% (Jounin 2014: 141142). As a result, African immigrants work more for white and other ethnic bosses and are in a formal relationship of being dominated. Therefore, in the workplace, ethnic identity has a very small impact on industrial relations, thus leaving room for the involvement of third parties such as the law and labor unions (Jounin 2014: 147).

Are migrant workers migrants first or workers first? Here, we discussed the multiple identities of Chinese domestic migrant workers, revealing the influence of ethnicity and its concomitant social relationship network on industrial relations. However, if Chinese laborers in France are compared with domestic migrant workers in China, we will find that ethnicity (which, in the context of domestic population mobility, means the place of origin, but in the context of international mobility means ethnicity) does have an impact on industrial relations, but the concrete function models are not the same. Tong Genxing's research on Hebei Baigou household luggage factories reflects that bosses have a phobia about identity recognition and solidarity among workers based on their place of origin. "My brother and I both are in luggage production business. I usually go to Shandong to recruit workers. He will go to Henan. Therefore, we usually avoid going to the same place." (Tong 2005: 68). According to the existing empirical research, Wen Xiang and Zhou Xiao made it clear that examinations should be carried out on the impact of native place on the labor process and industrial relations in the Chinese context. "Workers also take the initiative to form identity among themselves through ethnic groups, thus becoming the basis for unity" (Wen and Zhou 2007: 39). In terms of organization rights, self-organizations such as associations based on geographical relationships provide tangible social support to migrant workers, "playing an important role in the real work and life of migrant workers, such as providing work information and employment opportunities, collective rights protection, interpersonal contacts, and various interpersonal help, etc." (Chen and Liu 2010: 150). In addition, when Fan Lulu surveyed the garment industry in Jiaxing, she compared the two self-organizing modes of the cooperative production team and the contractor management team and found the complexity of the identity of the native place. Its impact on industrial relations is not necessarily the same, according to different production organization models. "In a cooperative production team, the identity of workers will exceed the geographical identity...and in the team managed by the contractor, the geographical identity will exceed the class identity" (Fan 2017: 55).

For domestic migrant workers in China, if the social relationship network formed on the basis of geography or native place plays more of a social support role, then for Chinese immigrant workers in France, ethnic narratives are often used to eliminate various labor-management conflicts in the labor process, and this has caused the ethnic identity of "Chinese in France" to often overlay the class identity of "immigrant labor." 


\section{The expectation of becoming a boss: temporality and the concealment of workers' narrative identity}

The concept of temporality (temporalité, Zeitlichkeit) comes from European philosophy, which emphasizes the personal life experience (vécu) of time. Luhmann (1976) once proposed that the fundamental characteristic of modern civil society is the temporalization of reality. Paul Ricoeur pointed out that human identity is a narrative identity (identité narrative), "which can be articulated only in the temporal dimension of human existence" (Ricoeur 1985, 1990). Daniel Mercure analyzes the diversity of social time and collective rhythm in an industrialized society and proposes that representations of the future (représentations de l'avenir) are class-oriented (Mercure 1995: 105). This theoretical clue enlightens us: Whether the working class exists as a subjective social group is based on how to recognize its common past and common future.

In most studies of labor processes, workers and bosses are analyzed in a structured and relatively fixed way. Whether it is a worker in a large capitalist factory, a migrant worker on a construction site or a waiter in the catering industry, the socioeconomic status of the employer and the employee is usually fixed, and workers can hardly move upwards within the enterprise through employment. However, in recent years, with the increasing research on small and medium-sized household enterprises in China, several studies have noted the possibility of the transformation of the identity of workers and bosses. In a small garment factory in Guangzhou, Zheng Guanghuai, and others found a great contrast between the poor working conditions of migrant workers and their actions of working hard and struggling to become a boss, thus suggesting that the "boss dream" formed the basis for workers to "consent" to poor and unstable work. (Zheng et al. 2015).

If the "boss dream" of domestic migrant workers is still a minority phenomenon in China, then in France, the "boss dream" of Chinese immigrant workers is a common perception. Some scholars have pointed out that the boundary between employees and bosses is constantly changing (Ma Mung 2009). Employees are more likely to become bosses, and bosses often become employees again because of poor management. This is quite common among Chinese immigrants. It is the so-called after this season will come another, and do not burn your bridges (Post 4-21st reply). Although Chinese immigrant workers do not have advanced skills and most of them are also employed (accounting for $57 \%$, far lower than other ethnic groups and immigrant averages), their social status is more likely to be transformed, and it is easier for them to become bosses than immigrant laborers of other ethnic groups (accounting for 13\%, far higher than other immigrant groups). Therefore, the social identity of Chinese immigrant workers is likely to be ambiguous.

Regardless of what percentage of workers actually become bosses, "becoming a boss" is a very common expectation for Chinese immigrant workers in France. One interviewee once described this to the author: "Soldiers who do not want to become generals are not good soldiers." During the interview, he was still an undocumented immigrant and relied on peddling some small commodities for a living, but becoming a boss was still his expectation for the future.

Because Chinese immigrants are mostly concentrated in small and medium-sized family enterprises, such enterprises rarely provide opportunities for upward movement; therefore, there is no room for upward mobility within the enterprise. If Chinese 
immigrant workers want to achieve upward social mobility, they must do so through cross-enterprise methods, that is, starting their own businesses and becoming their own bosses. Therefore, Chinese immigrants take their current status as temporary and transitional, and most workers plan to become their own bosses in the future. Based on this expectation, they regard their current living conditions and poor working conditions as temporary and have no strong desire to improve. Bosses and workers do not constitute two classes whose interests are at odds, but it is rather two different stages in the same career life. Today's workers will become tomorrow's bosses, and it is possible to replicate the same pattern on new arrivals.

In summary, we can see that, unlike other immigrant workers in France, Chinese workers have very strong expectations for their "transformation into bosses" in the future. In their identity narratives, they include a similar international migration past, a hard-working present, and a future of leaving the current social group and eventually joining the boss group. The workers' consciousness as a class is not evident, so the subjectivity is hidden in the narratives. Therefore, even if Chinese immigrant workers in France joined the labor union, they would not act as a class. This article argues that temporality plays a key role in the perception of immigrant workers' class subjectivity. The possible convertibility of worker-boss status helps to maintain the functioning of this kind of "overexploitation" in industrial relations.

\section{Conclusion: the possibility of resistance}

In France, the protection and support of workers' rights are relatively developed. Under this favorable structural condition, when labor conflicts occur, why do Chinese immigrant groups still prefer to take the "resistance of the weak" at the individual level rather than to take a collective and open approach? To understand this contradiction, this article mainly uses qualitative methods to further discuss the two types of exploitation on the basis of the demographic characteristics of Chinese immigrant labor groups, ways to find jobs, labor conditions, and the formation and characteristics of the Chinese ethnic labor market. The influence of multiple identities and temporality on class subjectivity and the significance of temporality in labor control are clarified.

On the one hand, this article focuses on workers' subjective perception of the "exploitation" phenomenon. Of course, such a research perspective does not deny the substantial existence of exploitation. In contrast, exploitation in the Marxist sense surely exists. This article aims to show how the phenomenon of exploitation is hidden in discourses, such as ethnic solidarity, and ultimately affects workers' subjective feelings.

On the other hand, this paper extends the discussion of labor control in previous studies to the dimension of temporality. Similar international immigration behaviors, shared immigrant life course, and expectations for future life-the temporality throughout the labor migration process-communicates the present, the past, and the future and reshapes the cognition of the present with expectations of the future and gives positive meaning to past experiences. As a result, the class confrontation between workers and bosses is eliminated, and the harsh and unstable working stage experienced by the workers seems to be the only way to achieve the upward mobility of social class because "everyone has experienced suffering."

It should be pointed out that this assumption is not only applicable to Chinese immigrant workers but also a management strategy and control method commonly used by 
many employers. In France, a labor sociology study of foreign immigrant workers at construction sites also found the employer's strategic use of upward social mobility. "I like to hire people who I think will develop in the enterprise over time...because of this, social conflicts no longer exist." (Jounin 2010: 76) Therefore, in the Chinese immigrant labor group, even if there is resistance, it only stays at the individual level, which is the stress response when the workers' wages are in arrears, and the purpose is only to demand payment of the wages in arrears. They still prefer to use "hidden transcripts" to resolve labor disputes.

Of course, not all Chinese immigrants are willing to accept this "chronic exploitation" mechanism. Immigrant workers who cannot accept this kind of labor condition and salary vote with their feet and leave the labor market of this ethnic group if they have an opportunity. According to the descriptions of residents of Community G and Chinese netizens, I simply summarize these people as international students, people from Hong Kong, people from Taiwan region, and "Chinese women marrying French men." What these groups of people have in common is that they are not completely confined to the circle of Chinese communities, but more or less have relatively close contact with French society and have an understanding of labor laws and labor rights. They are more likely to learn about their rights and be more intolerant when their rights are violated and therefore more likely to conflict with their employers. The most important thing is that, in the temporal dimension, they do not share similar "illegal stay" immigration experiences and have less expectation of being a boss in the future. In short, only when the socioeconomic backgrounds of Chinese immigrants in France become diverse is it possible for immigrant workers to protest against exploitation. Only the diversity inside Chinese immigrant groups will challenge the existing unspoken rules and economic models of the intragroup ethnic market. The objections and conflicts brought about by the challenge can make this pattern of exploitation more prominent so that people can realize the existence of this hidden mode of exploitation and its impact on the lives of immigrants, and public discussion and analysis of this mode will then become possible.

\section{Abbreviations}

CGT: Confédération générale du travail (General Confederation of Labour); INSEE: Institut national de la statistique et des études économiques (National Institute of Statistics and Economic Studies)

Acknowledgements

N/A.

Author's contributions

Juan $\mathrm{Du}$, conducted the collection and analysis of material, the theoretical framework, and the writing for the paper. The author(s) read and approved the final manuscript.

Funding

The authors declare no funding support.

Availability of data and materials

N/A. 
Received: 28 April 2020 Accepted: 2 July 2020

Published online: 20 August 2020

\section{References}

Alberti, Gabriella, Jane Holgate, and Maite Tapia. 2013. Organising migrants as workers or as migrant workers? Intersectionality, trade unions and precarious work. The International Journal of Human Resource Management 24 (22): 1008-1025.

Anderson, B. 2000. Doing the dirty work? The global politics of domestic labour. London/New York: Zed Books.

Anderson, B. 2010. Migration, immigration controls and the fashioning of precarious workers. Work, Employment and Society 24 (2): 300-317.

Auguin, Estelle. 2010. Le marché de l'emploi chinois en France: un système social au service de la réussite économique. In De l'ouvrier immigré au travailleur sans papiers. Les étrangers dans la modernisation du salariat, ed. Alain Morice and Swanie Potot, 163-176. Paris: Karthala.

Balthasar, M. 2017. Comment le droit du travail belge pourrait-il s'adapter face à une entreprise d'économie collaborative disruptive? Analyse de cas: Uber. (Unpublished master's thesis). Liège: Université de Liège.

Barron, Pierre, Anne Bory, Lucie Tourette, Sébastien Chauvin, and Nicolas Jounin. 2011. On bosse ici, on reste ici ! : La grève des sans-papiers : Une aventure inédite. Paris: La Découverte.

Beaud, Stéphane, and Florence Weber. 2010. Guide de l'enquête de terrain. Pairs: La Découverte.

Boltanski, Luc, and Laurent Thévenot. 1991. De la justification : les économies de la grandeur. Paris: Gallimard.

Braverman, H. 1974. Labor and monopoly capital: the degradation of work in the twentieth century. New York: Monthly Review Press.

Burawoy, Michael. 2008/1979. Manufacturing consent: changes in the labor process under monopoly capitalism, translated by Li Rongrong. Beijing: Commercial Press.

Castles, Stephen. 2006. Guestworkers in Europe: a resurrection? International Migration Review 40 (4): 741-766.

Castles, Stephen, and Godula Kosack. 1973. Immigrant workers and class structure in Western Europe. London: Oxford University Press.

Chen, Jiansheng, and Zhijun Liu. 2010. Joining a trade union or establishing self-organization —— thinking about migrant workers' right to organize. The Journal of Humanities 5: 147-154.

Du, J. 2014. Habiter entre marginalité et invisibilité : les immigrés chinois en sous-location en banlieue parisienne. Cahiers de I'Urmis 15 juillet (https://journals.openedition.org/urmis/1268).

Ezzy, Douglas. 1997. Subjectivity and the labour process: conceptualising 'Good Work. Sociology 31 (3): 427-444.

Fan, Lulu. 2017. The influence of native place, skill level, and gender on workers' self-organization. Journal of Social Development 2: 41-56.

Foucault, M. 1980. In Power/knowledge: selected interviews and other writings, ed. C. Gordon. New York: Pantheon Books.

Gao, Yun, and Véronique Poisson. 2005a. Le trafic et l'exploitation des immigrants chinois en France. Genève: Bureau international du Travail (https://www.files.ethz.ch/isn/44802/2005_Report_Le\%20traffic\%20et\%201\%20exploitation_FR.pdf).

Gao, Yun, and Véronique Poisson. 2005b. Nouvelles formes d'esclavage parmi les Chinois récemment arrivés en France. Hommes \& migrations 1254: 29-44.

Granotier, Bernard. 1970. Les travailleurs immigrés en France. Paris: La Découverte.

Granovetter, Mark. 2007/1985. Embeddedness: Social Network and Economic Action, translated by Luo Jiade. Beijing: Social Sciences Academic Press.

Guo, Yuhua. 2002. 'The weapons of the weak' and 'hidden transcripts' —- a study of the farmers' resistance with a perspective from bottom. Reading $7: 11-18$.

Hall, J.V., and A.B. Krueger. 2018. An analysis of the labor market for Uber's driver-partners in the United States. ILR Review 71 (3): 705-732.

Jounin, Nicolas. 2010. Des sans-papiers locaux à la sous-traitance internationale. Trajectoire d'un métier du bâtiment: le ferraillage. In De louvrier immigré au travailleur sans papiers. Les étrangers dans la modernisation du salariat, ed. Alain Morice and Swanie Potot, 69-91. Paris: Karthala.

Jounin, Nicolas. 2014. Aux origines des 'travailleurs sans papiers'. Les spécificités d'un groupe au service d'une identification généraliste. Revue européenne des migrations internationales 30 (1): 131-152.

Kahmann, Marcus. 2015. When the strike encounters the sans papiers movement: the discovery of a workers' repertoire of actions for irregular migrant protest in France. Transfer: European Review of Labour and Research 21 (4): 413-428.

Li, Xiangyi, and Min Zhou. 2014. The realization of social value of consumption in transnational spaces: Fuzhou immigrants in the United States. Sociological Studies 2: 43-64.

Liu, Jianzhou. 2011. Migrant workers' resistance and its significance to class formation —- a typological analysis. Youth. Studies 1: 33-43.

Luhmann, Niklas. 1976. The future cannot begin: temporal structures in modern society. Social Research 43 (1): 130-152

Ma Mung, Emmanuel. 2005. Chinese immigration and the (Ethnic) labour market in France. In Asian Migrants and European Labour Markets, ed. Ernst Spaan, Felicitas Hillmann, and Ton van Naerssen, 42-55. Abingdon: Routledge.

Ma Mung, Emmanuel. 2009. Le prolétaire, le commerçant et la diaspora. Revue européenne des migrations internationales 25 (1): $97-118$.

Maroukis, T. 2017. Migrant Care Workers' trajectories in a familistic welfare regime: labour market incorporation and the Greek economic crisis reality-check. Journal of Ethnic and Migration Studies 44 (14): 1-17.

Marx, Karl. 1972. Volume I of Capital, Volume 23 of Selected Works of Marx and Engels. Beijing: People's Publishing House.

McDowell, Linda, Adina Batnitzky, and Sarah Dyer. 2007. Division, Segmentation, and Interpellation: The Embodied Labors of Migrant Workers in a Greater London Hotel. Economic Geography 83 (1): 1-25.

McDowell, Linda, Adina Batnitzky, and Sarah Dyer. 2009. Precarious work and economic migration: emerging immigrant divisions of labour in greater London's service sector. International Journal of Urban and Regional Research 33 (1): 3-25.

Mercure, D. 1995. Les temporalités sociales. Paris: L'Harmattan.

Milkman, Ruth. 2006. L.A. Story: immigrant workers and the future of the U.S. labor movement. New York: Russell Sage Foundation. 
Milkman, Ruth. 2011. Immigrant workers, precarious work, and the US labor movement. Globalizations 8 (3): $361-372$. O'Doherty, D., and H. Willmott. 2001. Debating labour process theory: the issue of subjectivity and the relevance of poststructuralism. Sociology 35 (2): 457-476.

Pande, A. 2018. Intimate counter-spaces of migrant domestic workers in Lebanon. International Migration Review 52 (3): $780-808$.

Paul, A.M., and P. Neo. 2018. Am I allowed to be pregnant? Awareness of pregnancy protection laws among migrant domestic workers in Hong Kong. Journal of Ethnic and Migration Studies 44 (7): 1195-1213.

Piore, Michael. 1979. Birds of passage: migrant labor and industrial societies. Cambridge: Cambridge University Press.

Qi, Xin. 2011. The formation and reproduction of wage back-payment mechanism in Chinese construction industry. Sociological Studies 5: 55-79.

Ricoeur, Paul. 1985. Temps et récit. Paris: Seuil.

Ricoeur, Paul. 1990. Soi-même comme un autre. Paris: Seuil.

Scott, James C. 1985. Weapons of the weak: everyday forms of peasant resistance. New Haven: Yale University Press.

Scott, James C. 1990. Domination and the arts of resistance: hidden transcripts. New Haven. London: Yale University Press.

Scott, James C. 2001/1976. The moral economy of the peasant: rebellion and subsistence in Southeast Asia, translated by Cheng Lixian and Liu Jian. Nanjing: Yilin Press.

Shen, Yuan. 2008. L'hégémonie fondée sur les relations dans l'industrie du bâtiment. In La société chinoise vue par ses sociologues. Trans. by Camille Salques, ed. Jean-Louis Rocca, 93-129. Paris: Presses de Sciences Po.

Shen, Yuan, and Xiang Wen. 2014. Labor research from the perspective of transitional sociology. Chinese Workers. 5: 30-34. Storey, John. 1985. The means of management control. Sociology 19 (2): 193-211.

Tapia, Maite, and Lowell Turner. 2013. Union campaigns as countermovements: mobilizing immigrant workers in France and the United Kingdom. British Journal of Industrial Relations 51 (3): 601-622.

Tong, Genxing, 2005. Industrial workers at household in North Town: the logic of everyday practice and macro-political economy. Master's degree thesis of the Department of Sociology: Tsinghua University.

Tripier, Maryse. 1990. L'immigration dans la classe ouvrière en France. Paris: L'Harmattan.

Wang, Chunguang. 2000. Wenzhou people in Paris: a cross-social construction action of an immigrant group. Jiangxi: People's Publishing House.

Wen, Xiang, and Xiao Zhou. 2007. Western labor process theory and Chinese experience: a critical review. Social Sciences in China. 3: 29-39.

Whyte, W.F. 1956. Street Corner Society. Chicago: University of Chicago Press.

Zheng, Guanghuai, Hui Sun, and Xiangdong Wan. 2015. From 'the Game of Making Out' to 'the Game of Boss': labor control in the informal employment. Sociological. Studies. 3: 170-195.

Zhou, Min. 2010. Chinatown: the socioeconomic potential of an urban enclave. Philadelphia: Temple University Press.

\section{Publisher's Note}

Springer Nature remains neutral with regard to jurisdictional claims in published maps and institutional affiliations.

\section{Submit your manuscript to a SpringerOpen ${ }^{\circ}$ journal and benefit from:}

- Convenient online submission

- Rigorous peer review

- Open access: articles freely available online

High visibility within the field

- Retaining the copyright to your article

Submit your next manuscript at $\boldsymbol{\sim}$ springeropen.com 